\title{
THE LEAVES GOT IT RIGHT AGAIN: DNA PHYLOGENETICS SUPPORTS A SISTER-GROUP RELATIONSHIP BETWEEN EURYSTYLES AND LANKESTERELLA (ORCHIDACEAE: SPIRANTHINAE)
}

\author{
Gerardo A. Salazar ${ }^{1,3} \&$ Robert L. Dressler ${ }^{2}$ \\ ${ }^{1}$ Departamento de Botánica, Instituto de Biología, Universidad Nacional Autónoma de México, \\ Apartado Postal 70-367, 04510 Mexico, D.F., Mexico \\ ${ }^{2}$ Jardín Botánico Lankester, Universidad de Costa Rica. P. O. Box 1031-7050, Cartago, Costa Rica \\ ${ }^{3}$ Corresponding author: g.salazar@ibiologia.unam.mx
}

ABSTRACT. In spite of noticeable non-floral similarities such as their unusual epiphytic habit and vegetative morphology, Eurystyles and Lankesterella have been regarded by taxonomists who rank floral characters above all other sources of information as only distantly related. Here we assess the phylogenetic relationships of these genera, analyzing over 4500 characters of nuclear (nrITS) and plastid (matK-trnK, trnL-trnF) DNA sequences from 29 species/22 genera of Spiranthinae (plus appropriate outgroups); three structurally distinctive species of Eurystyles and two of Lankesterella were included. Both our parsimony and Bayesian phylogenetic analyses recovered Eurystyles and Lankesterella as sister taxa with strong internal support. The Eurystyles/Lankesterella clade is in turn supported as sister to the "Spiranthes clade." Our results agree with previous interpretations of a close relationship between these two genera based on their shared epiphytic habit and similar vegetative morphology, indicating that floral morphology is evolutionarily labile in these groups and thus less reliable as an indicator of phylogenetic relationship than more conservative vegetative morphology.

RESUMEN. A pesar de notables similitudes en características no florales, tales como su desusado hábito epífito y su morfología vegetativa, Eurystyles y Lankesterella han sido considerados como sólo distantemente relacionados entre sí por los taxónomos que valoran los atributos florales por encima de cualquier otra fuente de información. En este trabajo evaluamos las relaciones filogenéticas de estos géneros analizando más de 4500 caracteres de secuencias de ADN nuclear (nrITS) y de plástidos (matK-trnK, trnL-trnF) de 29 especies/22 géneros de Spiranthinae (y grupos externos apropiados); tres especies de Eurystyles estructuralmente distintas entre sí y dos de Lankesterella fueron incluidas. Tanto nuestro análisis de parsimonia como el de inferencia bayesiana recobran a Eurystyles y Lankesterella como taxones hermanos con fuerte apoyo interno. El clado Eurystyles/ Lankesterella a su vez está apoyado como hermano del "clado Spiranthes." Nuestros resultados concuerdan con interpretaciones previas de una relación cercana entre Eurystyles y Lankesterella basadas en el hábito epífito que comparten y su similar morfología vegetativa, indicando que la morfología floral es evolutivamente lábil en estos grupos y por lo tanto menos confiable como indicador de relaciones filogenéticas que la morfología vegetativa, más conservadora.

KEY WORDS: Orchidaceae, Spiranthinae, Eurystyles, Lankesterella, molecular phylogeny

"It is ironic that within a family known for its spectacular flowers and specialized floral morphology, vegetative characters are quickly gaining recognition as a better indicator of phylogenetic relationships for particular groups."

Kenneth M. Cameron, American Journal of Botany 92: 1025-1032 (2005).

The genera Eurystyles Wawra and Lankesterella Ames share several attributes that make them unique in subtribe Spiranthinae. The most obvious of these is their consistently epiphytic habit (Fig. 1A-B, 2A-B), in contrast with the ubiquitous terrestrial habit displayed by the nearly 40 other genera currently recognized in the subtribe (Schlechter, 1920; Dressler, 1981, 1993; Balogh, 1982; Garay, 1982; Burns-Balogh et al., 1985; Szlachetko, 1992; Salazar, 2003, 2005; Salazar et al., 2003). Furthermore, plants in both of these genera consist of small rosettes of lustrous, usually ciliate 
leaves that persist during several growth seasons, i.e. they are not deciduous as in other Spiranthinae, and their roots are fasciculate but comparatively slender instead of tuberous. Indeed, Eurystyles and Lankesterella are vegetatively so similar to one another that, in the absence of inflorescences, it is not always easy to identify to which genus a particular plant belongs (Johnson, 2001; Soto, 1993).

In contrast to their vegetative similarity, these two genera show striking differences in their reproductive structures. On the one hand, in Eurystyles the raceme is condensed (thus appearing capitate) and the numerous flowers are densely arranged in a spiral (Fig. 1B-D), whereas in Lankesterella the inflorescence consists of a lax, one-sided raceme bearing a few (usually 1-4) flowers (Fig. 2B, C). On the other hand, flowers of the two genera also differ in various structural details. In Eurystyles the bases of the sepals are inflated but do not form a distinct, retrorse spur. The base of the labellum usually is clawed and bears a retrorse, fleshy lobule at each side above the claw (except in Eurystyles subgenus Pseudoëurystyles (Hoehne) Szlach., in which the lip is sessile and lacks basal lobules). The gynostemium is free and elongated, and the rostellum, when present, usually forms a shallowly notched, membranaceous rostellum remnant upon removal of the pollinarium (Fig. 1E-H). In contrast, flowers of Lankesterella bear a retrorse spur, sessile labellum with marginal thickenings near the base, abbreviated gynostemium, and hard, pointed rostellum remnant (Fig. 2C-F).

The noticeable similarity in habit and vegetative structure between Eurystyles and Lankesterella led Dressler (1981), Soto (1993), and Salazar (2003, 2005) to advocate a close relationship between these two genera. Nevertheless, taxonomists who have preferred to classify orchids on the basis of floral characters to the exclusion of virtually all other biological evidence have disregarded such non-floral resemblance and instead considered these genera as distantly related, placing them in different generic alliances (Schlechter, 1920; Balogh, 1982; Burns-Balogh et al., 1985) or even distinct subtribes (Szlachetko, 1995; Szlachetko and Rutkowski, 2000; Szlachetko et al., 2005).

A recently published molecular phylogenetic analysis of Spiranthinae based on sequences of nuclear ribosomal ITS DNA (nrITS; Górniak et al., 2006) sustained a sistergroup relationship between Eurystyles and Lankesterella. However, that analysis included only one species each of Eurystyles and Lankesterella and was based on a single DNA region, which raised the question of whether such an "unorthodox" result (by floral taxonomist's standards) would hold true if increased numbers of taxa and characters were included in the analysis. In this study, we assess the phylogenetic position of Eurystyles and Lankesterella by conducting cladistic analyses with expanded sampling of both taxa and characters and also by analyzing nuclear (nrITS) as well as plastid (matK-trnK and trnLtrnF) DNA sequence data. Our aims are to clarify the relationships of Eurystyles and Lankesterella with one another and other members of Spiranthinae, as well as evaluate the reliability of vegetative versus floral characters as predictors of phylogenetic relationships in these genera against the background of the DNA sequence trees.

\section{Materials and methods}

Taxonomic sampling-Exemplars of three species of Eurystyles, two of Lankesterella, and 24 additional species of Spiranthinae (comprising in total 22 genera) were analyzed in this study. Representative species of all other subtribes of Cranichideae sensu Salazar et al. $(2003,2009)$ were used as outgroups. A list of the species analyzed with voucher information and GenBank accessions for DNA sequences is given in Table 1.

Although we sampled only three of the about 20 species of Eurystyles, they represent much of the reproductive structural variation displayed by the genus, which is reflected in the fact that the three species have been assigned by taxonomists to different sections, subgenera, and even different genera in the case of "Synanthes" [=Eurystyles] borealis (Heller) Burns-Bal., Robinson \& Foster (Burns-Balogh et al., 1985; Szlachetko, 1992). As for Lankesterella, the genus encompasses six to eight species (Garay, 1982; Szlachetko et al., 2005), all of which seem to be relatively uniform in most vegetative and reproductive morphological attributes.

Molecular methods-DNA extraction, gene amplification, and sequencing were carried out using standard protocols explained in Salazar et al. (2003) and Figueroa et al. (2008). Bidirectional sequence reads were obtained for all the DNA regions; chromatograms 

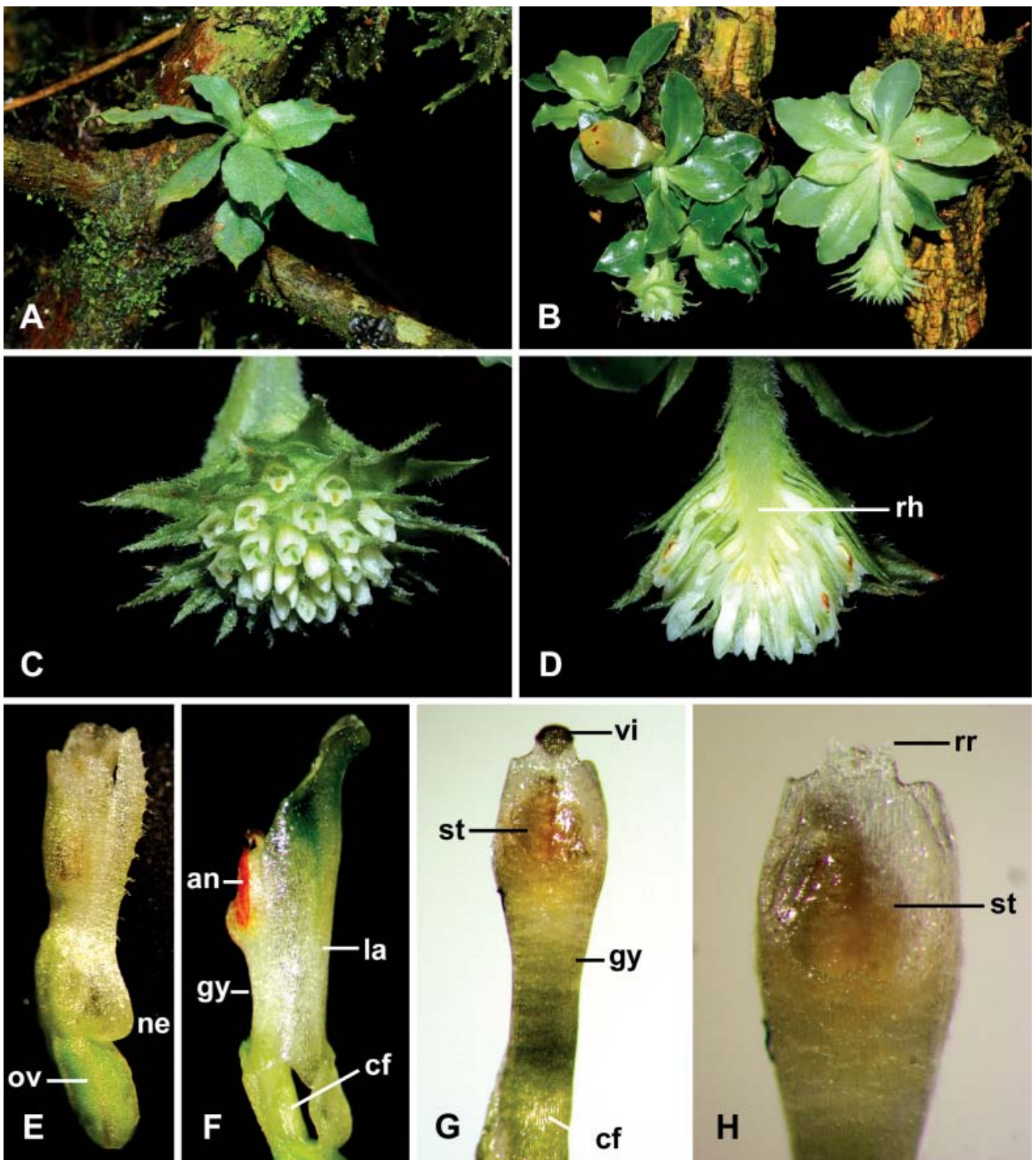

FIgure 1. Morphology of Eurystyles. A. Plant of Eurystyles cotyledon in situ in a cloud forest of southern Ecuador. B. Flowering plants of E. auriculata (left) and E. cotyledon (right) in cultivation. C. Inflorescence of E. cotyledon from below. D. Longitudinal section of the same inflorescence. E. Individual flower of E. cotyledon viewed obliquely from above and the side. F. Labellum and gynostemium of previous flower after the sepals and petals were excised. G. Gynostemium of E. cotyledon from below. H. Apex of previous gynostemium after removal of the pollinarium, showing the broadly notched rostellum remnant. Abbreviations: an = anther; $\mathrm{cf}=$ column foot; gy = gynostemium; la = labellum; ne = nectary; ov = ovary; $\mathrm{rh}=$ rachis of the raceme; $\mathrm{rr}=$ rostellum remnant; $\mathrm{st}=$ stigma; vi = viscidium. (B left, from Salazar 7646; B right-H, from Salazar 7642). Photographs by G. A. Salazar. 

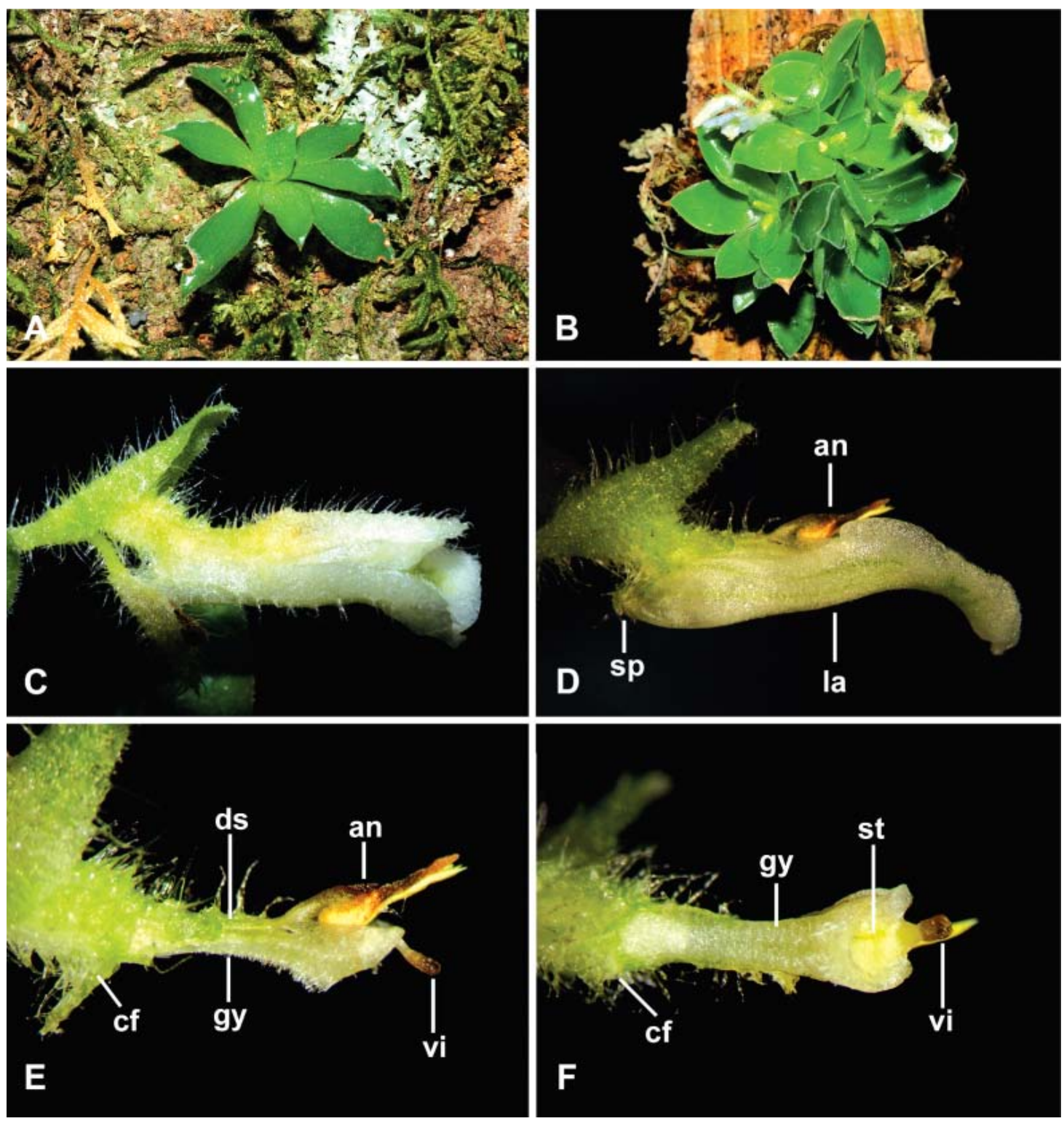

FIgURE 2. Morphology of Lankesterella. A. Lankesterella gnoma in situ in a mata atlántica of southeastern Brazil. B. Flowering plant of Lankesterella ceracifolia in cultivation. C. Close-up of a single-flowered inflorescence of the same plant. D. Labellum and column of previous flower after the sepals and petals were excised. E. Gynostemium from the side. F. Gynostemium from below. Abbreviations: an = anther; $\mathrm{cf}=$ column foot; ds = base of dorsal sepal (or ovary apex?) adnate to gynostemium; gy = gynostemium; la = labellum; sp = spur; st = stigma; vi = viscidium. (B-F from Salazar 7535). Photographs by G. A. Salazar.

were edited and assembled with Sequencher version 4.8 (GeneCodes Corp.). Alignment of the sequences was achieved by visual inspection in order to maximize sequence similarity (Simmons, 2004). No data were excluded from the analyses due to unambiguous alignment or for other reason, but individual gap positions were treated as missing data.

Cladistic analyses-From our previous molecular phylogenetic studies of Spiranthinae and other 
TABLE 1. Taxa studied, voucher information, and GenBank accessions.

\begin{tabular}{|c|c|c|c|c|}
\hline \multirow[t]{2}{*}{ Taxon } & \multirow[t]{2}{*}{ Voucher } & \multicolumn{3}{|c|}{ Gen Bank Accession } \\
\hline & & $\operatorname{trn} L-F$ & matK-trnK & ITS \\
\hline \multicolumn{5}{|l|}{$\begin{array}{l}\text { Subtribe Achlydosinae M.A.Clem. } \\
\text { \& D.L.Jones }\end{array}$} \\
\hline $\begin{array}{l}\text { Achlydosa glandulosa (Schltr.) } \\
\text { M.A.Clem. \& D.L.Jones }\end{array}$ & $\begin{array}{l}\text { New Caledonia, Clements D-285, } \\
\text { CANB }\end{array}$ & AJ544506 & AJ543950 & AJ539525 \\
\hline \multicolumn{5}{|l|}{ Subtribe Chloraeinae Rchb.f. } \\
\hline Chloraea magellanica Hook.f. & Chile, Ryan 1, K (spirit) & AJ544504 & AJ543948 & AJ539523 \\
\hline Gavilea lutea (Pers.) M.N.Correa & Chile, Ryan 3, K (spirit) & AJ544505 & AJ543949 & AJ539524 \\
\hline \multicolumn{5}{|l|}{ Subtribe Cranichidinae Lindl. } \\
\hline Aa colombiana Schltr. & Colombia, Aldana 2, ANDES & AM412731 & AM900802 & AM419766 \\
\hline Altensteinia fimbriata Kunth & $\begin{array}{l}\text { Ecuador, Salazar 6789, MEXU } \\
\text { (spirit) }\end{array}$ & AM412737 & AM900801 & AM419765 \\
\hline Cranichis engelii Rchb.f. & Ecuador, Schott s.n., K (spirit) & AM412721 & AM900814 & AM419779 \\
\hline $\begin{array}{l}\text { Galeoglossum thysanochilum (B.L.Rob. } \\
\text { \& Greenm.) Salazar }\end{array}$ & Mexico, Tenorio 17900, MEXU & AM412725 & AM900810 & AM419775 \\
\hline Gomphichis caucana Schltr. & Colombia, Diaz 159, ANDES & AM412736 & AM900805 & AM419770 \\
\hline Ponthieva racemosa (Walt.) C.Mohr & Mexico, Salazar 6049, MEXU & AJ544490 & AJ543936 & AJ539508 \\
\hline Porphyrostachys pilifera Rchb.f. & Peru, Whalley s.n., K (photograph) & AJ544496 & AJ543942 & AJ539514 \\
\hline Prescottia plantaginea Lindl. & Brazil, Salazar 6350, K (spirit) & AJ544493 & AJ543939 & AJ539511 \\
\hline Pterichis habenarioides Schltr. & Colombia, Aldana $12, \mathrm{COL}$ & AJ544491 & AJ543937 & AJ539509 \\
\hline $\begin{array}{l}\text { Stenoptera ecuadorana Dodson \& } \\
\text { C.Vargas }\end{array}$ & Ecuador, Salazar 6357, K (spirit) & AJ544494 & AJ543940 & AJ539512 \\
\hline \multicolumn{5}{|l|}{$\begin{array}{l}\text { Subtribe Galeottiellinae Salazar \& } \\
\text { M.W.Chase }\end{array}$} \\
\hline $\begin{array}{l}\text { Galeottiella sarcoglossa (A.Rich. \& } \\
\text { Galeotti) Schltr. }\end{array}$ & Mexico, Jiménez 2334, AMO & AJ544500 & AJ543945 & AJ539518 \\
\hline \multicolumn{5}{|l|}{ Subtribe Goodyerinae Klotzsch } \\
\hline Ludisia discolor (Ker-Gawl.) A.Rich. & $\begin{array}{l}\text { Tropical Asia (cultivated specimen), } \\
\text { Salazar 6354, K (spirit) }\end{array}$ & AJ544466 & AJ543911 & AJ539483 \\
\hline Pachyplectron arifolium Schltr. & New Caledonia, Chase 529, K & AJ544503 & $\mathrm{AJ} 310051$ & AJ539522 \\
\hline \multicolumn{5}{|l|}{ Subtribe Manniellinae Schltr. } \\
\hline $\begin{array}{c}\text { Manniella cypripedioides Salazar, } \\
\text { T.Franke, Zapfack \& Benkeen }\end{array}$ & Cameroon, Salazar et al. 6323, YA & AJ544498 & AJ543943 & AJ539516 \\
\hline
\end{tabular}




\begin{tabular}{|c|c|c|c|c|}
\hline \multirow[t]{2}{*}{ Taxon } & \multirow[t]{2}{*}{ Voucher } & \multicolumn{3}{|c|}{ Gen Bank Accession } \\
\hline & & $\operatorname{trn} L-F$ & matK-trnK & ITS \\
\hline Subtribe Pterostylidinae Pfitz. & & & & \\
\hline Pterostylis curta $\mathrm{R} . \mathrm{Br}$. & Australia, Chase $572, \mathrm{~K}$ & A.J544507 & AJ543951 & AJ539526 \\
\hline Subtribe Spiranthinae Lindl. & & & & \\
\hline $\begin{array}{l}\text { Aulosepalum tenuiflorum (Greenm.) } \\
\text { Garay }\end{array}$ & Mexico, Salazar 6017, MEXU & - & AJ543919 & - \\
\hline $\begin{array}{l}\text { Aulosepalum tenuiflorum (Greenm.) } \\
\text { Garay }\end{array}$ & Mexico, Salazar et al. $6150, \mathrm{MEXU}$ & AJ544474 & - & AJ539591 \\
\hline Beloglottis costaricensis (Rchb.f.) Schltr. & Mexico, Soto 8129, MEXU & AJ544475 & AJ543920 & AJ539492 \\
\hline Coccineorchis cernua (Lindl.) Garay & $\begin{array}{l}\text { Panama, Salazar et al. } 6249 \text {, MEXU } \\
\text { (spirit) }\end{array}$ & AJ544485 & AJ543930 & AJ539502 \\
\hline $\begin{array}{l}\text { Cyclopogon epiphyticum (Dodson) } \\
\text { Dodson }\end{array}$ & Ecuador, Salazar 6355, K & AJ544482 & AJ543927 & AJ539499 \\
\hline Deiregyne diaphana (Lindl.) Garay & Mexico, Salazar et al. 6172, MEXU & AJ544467 & AJ543912 & AJ539484 \\
\hline $\begin{array}{l}\text { Dichromanthus aurantiacus (La Llave \& } \\
\text { Lex.) Salazar \& Soto Arenas }\end{array}$ & Mexico, Salazar 6351, K (spirit) & AJ5 544468 & AJ543913 & AJ539485 \\
\hline $\begin{array}{l}\text { Dichromanthus cinnabarinus (La Llave } \\
\text { \& Lex.) Garay }\end{array}$ & Mexico, Linares 4469, MEXU & AJ544469 & AJ543914 & AJ539486 \\
\hline $\begin{array}{l}\text { Eltroplectris calcarata (Sw.) Garay \& } \\
\text { H.R.Sweet }\end{array}$ & Brazil, Soares s.n., K (photograph) & AJ519452 & AJ519450 & AJ519448 \\
\hline Eurystyles auriculata Schltr. & $\begin{array}{l}\text { Costa Rica, Dressler s.n., MEXU } \\
\text { (spirit) }\end{array}$ & FN556166 & FN556171 & FN556161 \\
\hline Eurystyles borealis A.H.Heller & Mexico, Soto 9149, AMO & AJ544480 & AJ543925 & AJ539497 \\
\hline Eurystyles cornu-bovis Szlach. & Panama, Maduro 230, FLAS & FN556167 & FN556172 & FN556162 \\
\hline $\begin{array}{l}\text { Funkiella hyemalis (A.Rich. \& Galeotti) } \\
\text { Schltr. }\end{array}$ & Mexico, Salazar et al. 6128 , MEXU & AJ544478 & AJ543923 & AJ539495 \\
\hline Hapalorchis lineatus (Lindl.) Schltr. & $\begin{array}{l}\text { Puerto Rico, Ackerman } 3648 \text {, } \\
\text { UPRRP }\end{array}$ & FN556170 & FN556175 & FN556165 \\
\hline $\begin{array}{l}\text { Lankesterella ceracifolia (Barb.Rodr.) } \\
\text { Ames }\end{array}$ & $\begin{array}{l}\text { Argentina, Salazar } 7535 \text {, MEXU } \\
\text { (spirit) }\end{array}$ & FN556169 & FN556174 & FN556164 \\
\hline Lankesterella gnoma (Kraenzl.) Hoehne & Brazil, Warren s.n., K (spirit) & FN556168 & FN556173 & FN556163 \\
\hline $\begin{array}{l}\text { Mesadenella petenensis (Standl. \& } \\
\text { L.O.Williams) Garay }\end{array}$ & Mexico, Salazar 6069, MEXU & AJ544486 & AJ543931 & AJ539503 \\
\hline Mesadenus lucayanus (Britt.) Schltr. & Mexico, Salazar 6043, MEXU & AJ544471 & AJ543916 & AJ539488 \\
\hline
\end{tabular}




\begin{tabular}{|c|c|c|c|c|}
\hline \multirow[t]{2}{*}{ Taxon } & \multirow[t]{2}{*}{ Voucher } & \multicolumn{3}{|c|}{ Gen Bank Accession } \\
\hline & & $\operatorname{trn} L-F$ & matK-trnK & ITS \\
\hline \multicolumn{5}{|l|}{ Subtribe Spiranthinae Lindl. } \\
\hline $\begin{array}{l}\text { Microthelys minutiflora (A.Rich. \& } \\
\text { Galeotti) Garay }\end{array}$ & Mexico, Salazar et al. 6129, MEXU & AJ544477 & AJ543922 & AJ539494 \\
\hline Odontorrhynchus variablis Garay & Chile, Wallace $130 / 85$, CANB & AJ544481 & A.J543926 & AJ539498 \\
\hline Pelexia adnata (Sw.) Poit. ex Spreng. & Mexico, Salazar 6012, MEXU & AJ544484 & AJ543929 & AJ539501 \\
\hline Sacoila lanceolata (Aubl.) Garay & Brazil, Da Silva 874, MG & AJ544529 & AJ543933 & - \\
\hline Sacoila lanceolata (Aubl.) Garay & Panama, Förther 2545, M & - & - & AJ539504 \\
\hline Sarcoglottis acaulis (J.E.Sm.) Schltr. & Trinidad, Salazar 6356, K (spirit) & AJ544483 & AJ543928 & AJ539500 \\
\hline Schiedeella faucisanguinea (Dod) & Mexico, Jiménez s.n., AMO & AJ544479 & AJ543924 & AJ539496 \\
\hline \multicolumn{5}{|l|}{ Burns-Bal. } \\
\hline Schiedeella llaveana (Lindl.) Schltr. & Mexico, Salazar 6073, MEXU & AJ544470 & - & - \\
\hline Schiedeella llaveana (Lindl.) Schltr. & Mexico, Salazar 6105, MEXU & - & AJ543915 & AJ539487 \\
\hline Spiranthes cernua (L.) Rich. & USA, Nickrent 4188 , MEXU & AJ544472 & AJ543916 & AJ539489 \\
\hline Spiranthes spiralis (L.) Cheval. & $\begin{array}{l}\text { United Kingdom, Bateman s.n., K } \\
\text { (spirit) }\end{array}$ & AJ544473 & AJ543918 & AJ539490 \\
\hline Stenorrhynchos glicensteinii Christenson & Mexico, Salazar 6090, MEXU & AJ544487 & AJ543532 & AJ539505 \\
\hline $\begin{array}{l}\text { Svenkoeltzia congestiflora } \\
\text { (L.O.Williams) Burns-Bal. }\end{array}$ & Mexico, Salazar 6143, MEXU & AJ544476 & AJ543921 & AJ539493 \\
\hline
\end{tabular}

Cranichideae (Salazar et al., 2003, 2009; Figueroa et al., 2008), it has become evident that combined analyses of the DNA sequence data that we are analyzing here increases resolution and internal clade support as compared with the separate analyses. Therefore, our approach here was to analyze all data sets in combination. The combined matrix was thus analyzed by two different phylogenetic methods: maximum parsimony and Bayesian inference. The parsimony analysis was conducted with the computer program PAUP* version $4.02 \mathrm{~b}$ for Macintosh (Swofford, 2002), and consisted of a heuristic search with 1000 replicates of random taxon addition for the starting trees and tree rearrangements using tree bisection-reconnection ("TBR") branch-swapping; the option "MULTREES" was activated (to allow for storage in memory of multiple trees), and all most-parsimonious trees (MPTs) were saved. All characters were treated as unordered and had equal weights (Fitch, 1971). Internal support for clades was assessed by bootstrapping (Felsenstein, 1985), for which 300 bootstrap replicates were performed, each with 20 replicates with random taxon addition and TBR branch-swapping, keeping up to 20 mostparsimonious trees from each addition replicate. The Bayesian analysis was carried out using the program MrBayes version 3.1.2 for Macintosh (Ronquist et al., 2005). The best-fitting models of nucleotide substitution for five character partitions (nrITS region, matK pseudogene, trnK intron, trnL intron, and $\operatorname{trnL}$-trnF intergenic spacer) were selected using the Akaike Information Criterion (Akaike, 1974) with the program Modeltest 3.7 (Posada and Crandall, 1998). In all instances, a six-parameter model with among-site rate heterogeneity modeled according to a gamma distribution and a proportion of invariant 
characters was selected, except that for the $\operatorname{trn} K$ intron there were no invariant characters. Thus, two character partitions were declared in MrBayes, one including the trnK intron and another encompassing all the other sequence data, specifying the appropriate models. All model parameters were unlinked among the five character partitions, allowing each group of characters to have its own set of parameters (Ronquist et al., 2005). Two simultaneous analyses were run for $1,000,000$ generations, sampling from the trees every hundredth generation under the default conditions of MrBayes for the Markov chains. The first 250,000 generations (2500 trees) of each run were discarded as the burn-in. Inferences about relationships and posterior probabilities of clades (PP) were based on a majority-rule summary tree constructed by pooling the remaining 15,000 trees.

\section{Results}

Parsimony analysis - The concatenated data set consisted of 4549 characters, 1066 (23\%) of which were potentially parsimony-informative. The heuristic search recovered six most parsimonious trees with a length of 4381 steps, consistency index (excluding uninformative characters) of 0.45 , and retention index of 0.64 . The six cladograms differed only in the resolution among species of Eurystyles and in whether or not the Stenorrhynchos and Pelexia clades (see below) are sisters with one another. However, none of the alternative resolutions received bootstrap support [BS] greater than $50 \%$. One of the six trees is shown in Figure 3A. The same tree, which is topologically identical to the Bayesian consensus and on which bootstrap percentages and posterior probabilities (from the Bayesian analysis; see below) were included for the pertinent clades, is depicted in Figure 3B. Four major clades were recovered within strongly supported Spiranthinae (BP 100; Fig. 3A, B): 1) the Stenorrhynchos clade (Stenorrhynchos glicensteinii through Sacoila lanceolata; BP 98\%); 2) the Pelexia clade (Coccineorchis cernua through Pelexia adnata; BP $80 \%)$; 3) a strongly supported clade consisting of Eurystyles and Lankesterella (BP 100\%); and 4) a strongly supported Spiranthes clade (Hapalorchis lineatus through Dichromanthus cinnabarinus; BP 86\%). Eurystyles and Lankesterella are in turn moderately supported as collective sisters to the Spiranthes clade.

Bayesian analysis - The majority-rule consensus calculated from 15,000 trees from the Bayesian analysis was fully resolved and topologically identical to the parsimony tree of Figure 3A. Posterior probabilities (PP) of clades are displayed in Figure 3B. Like parsimony, the Bayesian analysis recovered a strongly supported clade consisting of Eurystyles and Lankesterella (PP 1.00).

\section{Discussion}

Our parsimony and Bayesian analyses recovered the same phylogenetic patterns, both supporting Eurystyles and Lankesterella as forming a strongly supported clade. These congruent results are significant, given the disproportionately long branches subtending Eurystyles and Lankesterella (in the parsimony tree portrayed Figure $3 \mathrm{~A}$, the branch leading to Eurystyles is 124 steps long, whereas that of Lankesterella is 116 steps long). It has been proposed that parsimony may be inconsistent as a method of phylogeny reconstruction when different groups within a lineage evolve at dissimilar rates (Felsenstein, 1978, 2004; Hendy \& Penny, 1989) because of an analytical artefact known as "long-branch attraction," which occurs when long-branched lineages that are not each other's closest relatives are grouped because of similarities due to independent substitutions to the same base from different ancestral bases (e.g. Lewis, 1998; Sanderson et al., 2000; Anderson \& Swofford, 2004; Bergsten, 2005). Methods based on stochastic models of nucleotide substitution such as maximum likelihood and Bayesian inference, however, have been shown to be less sensitive to such conditions (see Swofford et al., 1996; Lewis, 1998; Felsenstein, 2004; Bergsten, 2005). In these analyses, both parsimony and Bayesian inference recovered the same tree topology, indicating that the strongly supported placement of Eurystyles and Lankesterella as sister groups is not an artefact of long branches misleading parsimony.

Our results are in full agreement with the remarkable similarities in habit and vegetative structure between Eurystyles and Lankesterella, in spite of their disparity in reproductive attributes. Such disparity might actually have been overstated, and 


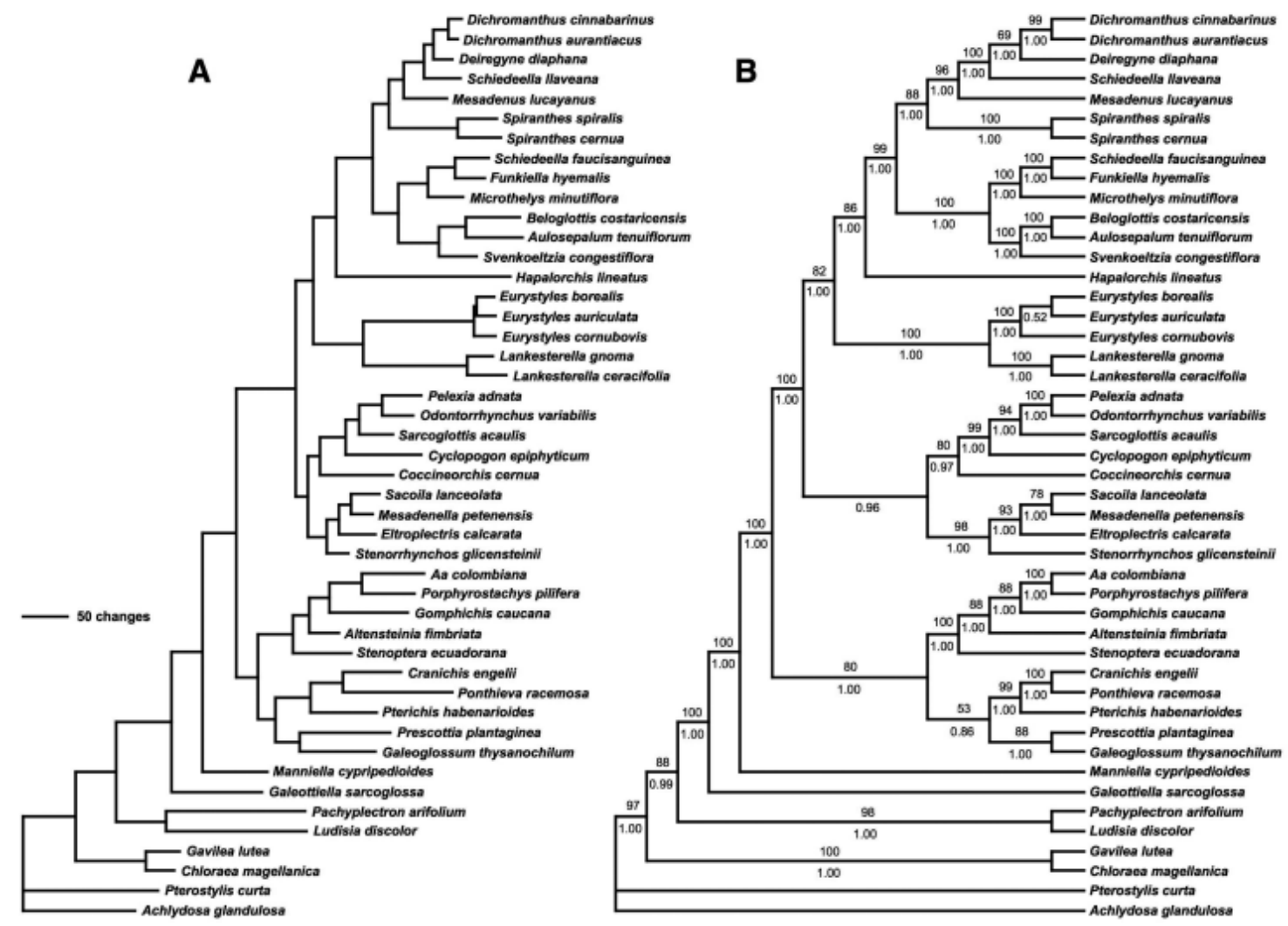

FIGURE 3. Phylogenetic relationships of Eurystyles, Lankesterella, and other Spiranthinae inferred from combined nuclear ITS and plastid trnK-matK and trnLtrnF DNA sequences. A. One of the six shortest trees recovered by the parsimony analysis, with branch lengths drawn proportional to the number of character changes supporting them; arrows point to clades that collapse in the strict consensus. B. Same parsimony tree as in A, which was topologically identical to the Bayesian summary tree, and on which bootstrap percentages (numbers above branches) and posterior probabilities from the Bayesian analysis (numbers below branches) are superimposed (see text).

upon closer scrutiny the morphological gap between these genera appears not as large as it would appear at first glance. For instance, and quoting Szlachetko (1992), labellum structure between Eurystyles subgen. Pseudoëurystyles and Lankesterella "is almost identical." Overall flower structure is much the same in both genera, and although species of Eurystyles lack the pointed retrorse spur, the base of their floral tube always is distinctly inflated (compare Fig. 1E and 2D).

Gynostemium morphology between these genera as described in the literature seems to be dissimilar, with the gynostemium of Lankesterella often being interpreted as relatively short, with an "obscure to short" column part (Szlachetko \& Rutkowski, 2000; Szlachetko et al., 2005) and a prominent column foot. However, in the fresh material of Eurystyles and Lankesterella that we have examined the gynostemia look similar, with the main difference being that, in Lankesterella, the basal portion of the dorsal sepal or the apex of the ovary (or both) is adnate to the back of the gynostemium (indicated in Figure 2E as "ds"). Were it not for this adnation, the proportions of column part to column foot of both genera would look even more similar.

The most distinctive feature separating the two genera is the rostellum, which after removal of the pollinarium in Lankesterella usually leaves a hard narrow point that is absent in Eurystyles. However, Eurystyles shows substantial structural variation (see Szlachetko, 1992; Szlachetko \& Rutkowski, 2000), 
and both Eurystyles and Lankesterella are known for their frequent, seemingly autogamous forms, in which rostella and viscidia are reduced, non-functional or missing altogether (Szlachetko, 1992; Salazar, 2003). These phenomena indicate that rostellum morphology in these groups is evolutionarily labile.

The abovementioned differences in reproductive structures between these two genera are almost certainly related to different pollination mechanisms. Unfortunately, nothing is known about their natural pollination besides the aforementioned recurrence of autogamy. The inflorescences of Eurystyles auriculata and E. cotyledon produce conspicuous, pleasant, diurnal odors, which might play a role in pollinator attraction. Their pendulous, dense clusters of tubular, fragrant flowers with nectar at the bottom of the floral tube may be pollinated by small insects (possibly lepidopterans) that probe many flowers in search of food. However, we have had limited opportunities to examine fresh inflorescences of Lankesterella in the field, and we are unable at this time to confirm whether they are also fragrant or not.

Given the unusual (in subtribe Spiranthinae) epiphytic habit of Eurystyles and Lankesterella on the one hand and their long branches in the molecular tree on the other, one has to ask whether there may be a relationship between epiphytism and an accelerated rate of molecular evolution in these genera. However, the branch of Hapalorchis lineata (Fig. 3A), a terrestrial species, is even longer (194 steps). Therefore, drawing conclusions in this respect is not possible at this time, but it will be interesting to address this matter as more sequences of these and other genera of the subtribe become available.

In closing, it is worth mentioning that our results mirror those of Cameron's (2005) molecular phylogenetic study of Malaxideae (from which our epigraph was taken) in showing that at least in some particular orchid groups vegetative structure might be a better predictor of phylogenetic relationships than floral attributes. In both the epidendroid tribe Malaxideae and the orchidoid subtribe Spiranthinae, vegetative features prove to be more conservative than floral details. Indeed, speciation in these groups often appears to involve the evolution of different floral features in closely allied species, with the result that the species are pollinated by different agents, or in different ways, and the species coexist without interbreeding. There may also be parallelisms in floral features between quite different groups, as in Trichocentrum Poepp. \& Endl. and other Oncidiinae, flowers of which mimic the flowers of Malpighiaceae, with or without oil glands (see Chase et al., 2009 and references included there). Thus, one might expect that floral features are more variable and vegetative features more conservative, despite unwarranted assumptions to the contrary (e.g. Szlachetko \& Rutkowski, 2000). This, of course, is a generalization. There are certainly parallelisms to be found among vegetative features just as there are among floral features. When in doubt, trust neither the leaves nor the flowers, but the DNA.

ACKNOWLEDGMENTS. We thank the Curators of AMES, AMO, COL, JBSD, K, MEXU, MO, NY, SEL, US, USJ, and VEN for courtesies extended during study of their orchid collections; Jim Ackerman, Pilar Candela, José Linares, Andrés Maduro, and Dick Warren for plant material; José Portilla and the staff of Ecuagenera and the "Centro de Estudios Científicos de Orquídeas Andinas Padre Ángel Andreetta," as well as Lorena Endara, Lou Jost, and Harry Zelenko for hospitality and support during our field observations in Ecuador; Cássio van den Berg for enjoyable company and expert guidance to G.A.S. during orchid observations in Brazil; two anonymous reviewers for useful suggestions to a previous version of the manuscript; and Laura Márquez Valdelamar and Lidia I. Cabrera for assistance with DNA sequencing.

\section{LITERATURE CITED}

Akaike, H. 1974. A new look at the statistical model identification. IEEE Transactions on Automatic Control 19: 716-723.

Anderson, F. E. \& D. L. Swofford. 2004. Should we be worried about long-branch attraction in real data sets? Investigations using metazoan 18S rDNA. Molec. Phylogen. Evol. 33: 440-451.

Balogh, P. 1982. Generic redefinition in subtribe Spiranthinae (Orchidaceae). Am. J. Bot. 69: 1119-1132.

Burns-Balogh, P. 1986. Synopsis de la tribu [sic] Spiranthinae en México. Orquídea (Mexico City), n.s. 10: 47-96.

Burns-Balogh, P., H. Robinson \& M. S. Foster. 1985. The capitate-flowered epiphytic Spiranthinae (Orchidaceae) and a new genus from Paraguay. Brittonia 37: 154-162.

Bergsten, J. 2005. A review of long-branch attraction. Cladistics 21: 163-193.

Cameron, K. M. 2005. Leave it to the leaves: a molecular 
phylogenetic study of Malaxideae (Epidendroideae, Orchidaceae). Am. J. Bot. 92: 1025-1032.

Chase, M. W., N. H. Williams, A. Donisete de Faria, K. M. Neubig, M. do C. E. Amaral \& W. M. Whitten. 2009. Floral convergence in Oncidiinae (Cymbidieae; Orchidaceae): an expanded concept of Gomesa and a new genus Nohawilliamsia. Ann. Bot. 104: 387-402.

Dressler, R. L. 1981. The orchids: natural history and classification. Harvard University Press, Cambridge, Massachusetts, USA

Dressler, R. L. 1993. Phylogeny and classification of the orchid family. Dioscorides Press, Portland, Oregon, USA.

Felsenstein, J. 1978. Cases in which parsimony or compatibility methods will be positively misleading. Syst. Zool. 27: 401-410.

Felsenstein, J. 1985. Confidence limits on phylogenies: an approach using the bootstrap. Evolution 39: 783-791.

Felsenstein, J. 2004. Inferring phylogenies. Sinahuer, Sunderland, Massachusetts, USA.

Figueroa, C., G. A. Salazar, A. Zavaleta \& M. Engleman, M. 2008. Root character evolution and systematics in Cranichidinae, Prescottiinae and Spiranthinae (Orchidaceae, Cranichideae). Ann. Bot. 101: 509-520.

Fitch, W. M. 1971. Toward defining the course of evolution: minimum change for a specific tree topology. Syst. Zool. 20: 406-416.

Garay, L. A. 1982. A generic revision of the Spiranthinae. Bot. Mus. Leaf. 28: 277-425.

Górniak, M., J. Mytnik-Ejsmont, P. Rutkowski, P. Tukałło, J. Minasiewicz \& D. L. Szlachetko. 2006. Phylogenetic relationships within the subtribe Spiranthinae s.l. (Orchidaceae) inferred from the nuclear ITS region. Biodiv. Res. Cons. 1-2: 18-24.

Hendy, M. D. \& D. Penny. 1989. A framework for the quantitative study of evolutionary trees. Syst. Zool. 38: 297-309.

Johnson, A. E. 2001. Las orquídeas del Parque Nacional Iguazú. Literature of Latin America, Buenos Aires, Argentina.

Lewis, P. O. 2001. Phylogenetic systematics turns over a new leaf. Trends Ecol. Evol. 16: 30-37.

Ronquist, F., J. P. Huelsenbeck \& P. van der Mark. 2005. MrBayes 3.1 manual, draft 5/17/2005. Program Documentation and Manual. Website at http:// morphbank.ebc.uu.se/mrbayes/.

Salazar, G. A., 2003. Spiranthinae. Pp. 22-23 in: A. M.
Pridgeon, P. J. Cribb, M. W. Chase, \& F. N. Rasmussen (eds.), Genera Orchidacearum, Volume 3. Orchidoideae part 2, Vanilloideae. Oxford University Press, UK.

Salazar, G. A. 2005. Eurystyles Wawra. Pp. 320-321 in: F. Pupulin (ed.), Vanishing beauty: native Costa Rican orchids, Vol. 1. Universidad de Costa Rica, San José, Costa Rica.

Salazar, G. A., M. W. Chase, M. A. Soto \& M. Ingrouille. 2003. Phylogenetics of Cranichideae with emphasis on Spiranthinae (Orchidaceae, Orchidoideae): evidence from plastid and nuclear DNA sequences. Am. J. Bot. 90: 777- 795 .

Salazar, G. A., L. I. Cabrera, S. Madriñán \& M. W. Chase. 2009. Phylogenetic relationships of Cranichidinae and Prescottiinae (Orchidaceae, Cranichideae) inferred from plastid and nuclear DNA sequences. Ann. Bot. 104: 403-416.

Soto, M. A. 1993. Eurystyles, a new generic record for the Mexican orchid flora. Orquídea (Mexico City), n.s. 13: 269-274.

Sanderson, M. J., M. F. Wojciechowski, J. -M. Hu, T. Sher Kahn \& S. G. Brady. 2000. Error, bias, and long-branch attraction in data for two chloroplast photosystem genes in seed plants. Molec. Biol. Evol. 17: 782-797.

Swofford, D. L. 2002. PAUP*. Phylogenetic analysis using parsimony (*and other methods). Version 4. Sinauer, Sunderland, Massachusetts, USA.

Swofford, D. L., G. J. Olsen, P. J. Waddell \& D. M. Hillis. 1996. Phylogenetic inference. Pp. 407-514 in: D. L. Hillis, C. Moritz \& B. K. Mable (eds.), Molecular systematics, 2nd edition. Sinhauer, Sunderland, Massachusetts, USA.

Szlachetko, D. L. 1992. Notes on Eurystyles (Orchidaceae), with a description of a new species from Mesoamerica. Fragmenta Flor. Geobot. 37: 13-19.

Szlachetko, D. L. 1995. Systema orchidalium. Fragmenta Floristica et Geobotanica (Supplement) 3: 1-152.

Szlachetko, D. L. \& P. Rutkowski. 2000. Gynostemia orchidalium I. Apostasiaceae, Cypripediaceae, Orchidaceae (Thelymitroideae, Orchidoideae, Tropidioideae, Spiranthoideae, Neottioideae, Vanilloideae). Acta Bot. Fennica 169: 1-379.

Szlachetko, D. L., P. Rutkowski \& J. Mytnik. 2005. Contributions to the taxonomic revision of the subtribes Spiranthinae, Stenorrhynchidinae and Cyclopogoninae (Orchidaceae) in Mesoamerica and the Antilles. Polish Bot. Stud. 20: 3-387. 